\title{
PROSES BERPIKIR MAHASISWA DALAM MEMECAHKAN MASALAH FUNGSI PEMBANGKIT
}

\author{
Ninik Mutianingsih ${ }^{1}$, Lydia Lia Prayitno ${ }^{2}$, Agus Prasetyo Kurniawan ${ }^{3}$ \\ 1,2Pendidikan Matematika, Universitas PGRI Adi Buana Surabaya \\ ${ }^{3}$ Pendidikan Matematika, UIN Sunan Ampel Surabaya
}

\begin{abstract}
This study aims to describe students' thinking process in solving the problems of generating function. This is a case study that classifies students into three categories: high, medium, and low. Subjects were asked to solve the problems then use think aloud to reveal their thinking process. The results show that in understanding the problem, using conceptual and procedural knowledge related to the problems, strategies, and experiences they have in solving similar problems between the three subjects is different. Subjects with high and medium capability are able to reveal the problem-solving component of Polya in detail, whereas low-ability subjects use only some of the problem-solving components of Polya.
\end{abstract}

Keywords: Thinking process; Problem solving; Generating function.

\section{PENDAHULUAN}

Berpikir merupakan aktivitas melibatkan pikiran manusia yang digunakan untuk mengambil keputusan melalui informasi yang diberikan untuk memecahkan masalah dalam kehidupan sehari-hari. Berpikir merupakan sebuah proses dinamis yang dilalui seseorang, sehingga hal ini dapat dijelaskan melalui proses yang dilakukan. Hal inilah yang dinamakan dengan proses berpikir (Subanji \& Nusantara, 2016). Salah satu tugas pokok pendidikan yaitu menjelaskan proses berpikir siswa dalam mempelajari matematika (Marpaung, 1993).

Salah satu komponen penting dalam mempelajari matematika adalah pemecahan masalah (NCTM, 2000). Lebih lanjut, NCTM (2000) menyatakan melalui pemecahan masalah matematika memberikan cara pada siswa untuk berpikir dan memiliki perilaku positif. Pemecahan masalah merupakan kegiatan berpikir, sedangkan berpikir sendiri merupakan proses, jadi pemecahan masalah merupakan sebuah proses. Proses berpikir dalam memecahkan masalah merupakan hal terpenting dibandingkan jawaban yang dihasilkannya. Oleh karena itu, dalam proses pembelajaran harus diajarkan bagaimana siswa mampu menjelaskan proses berpikirnya dalam memperoleh jawaban, bukan hanya sekedar hasil akhirnya saja. 
Ketika berbicara tentang pemecahan masalah tentunya tidak terlepas dari strategi pemecahan masalah. Salah satu strategi pemecahan masalah yang biasa digunakan antara lain strategi pemecahan masalah menurut Polya (2004). Polya mengungkapkan dalam memecahkan masalah menggunakan empat langkah yaitu a) memahami masalah, b) merencanakan penyelesaian, c) menyelesaikan masalah sesuai rencana, dan d) melakukan pengecekan. Jadi dalam menyelesaikan suatu permasalahan setidaknya harus mampu memahami masalah yang ada, kemudian melakukan perencanaan penyelesaian dari masalah tersebut. Setelah melakukan perencanaan langkah selanjutnya adalah menyelesaikan sesuai dengan rencana yang telah disusun dan terakhir melakukan pengecekan kembali dari proses penyelesaian yang telah dilakukan.

Penelitian tentang proses berpikir dalam memecahkan masalah telah dilakukan oleh beberapa peneliti. Bakry dan Bakar (2015) meneliti tentang proses berpikir siswa SMP menggunakan Higher Order Thinking Skills (HOTS) dalam memecahkan masalah. Mairing (2017) tentang proses berpikir siswa SMA kelas XI dalam memecahkan masalah berdasarkan tahapan Polya. Rahman dan Ahmar (2016) meneliti tentang level berpikir siswa ketika memecahkan masalah. Sedangkan, penelitian Sukoriyanto, Nusantara, Subanji, dan Chandra (2016a) menggunakan kerangka kerja asimilasi dan akomodasi ketika mahasiswa memecahkan masalah kombinasi ditinjau dari kemampuan siswa. Berdasarkan beberapa penelitian yang diungkapkan di atas, belum ada penelitian yang membahas tentang proses berpikir mahasiswa dalam memecahkan masalah fungsi pembangkit berdasarkan kemampuan tinggi, sedang, dan rendah berdasarkan tahapan Polya.

Kirkley mengungkapkan bahwa pemecahan masalah merupakan perwujudan dari suatu aktivitas mental yang terdiri dari bermacam-macam keterampilan dan tindakan kognitif dan bertujuan untuk mendapatkan solusi yang benar dari masalah (Anggo, 2009). Pada dasarnya pemecahan masalah melibatkan tindakan kognitif, yang berimplikasi pada kemampuan setiap mahasiswa sehingga tidak akan sama. Jadi, perlu diadakan penelitian lebih lanjut tentang proses berpikir mahasiswa dalam memecahkan masalah.

Pada mata kuliah matematika diskrit diperlukan penerapan rumus untuk menyelesaikan masalah matematika, sehingga diharapkan mahasiswa memiliki kemampuan pemecahan masalah (Suryati, 2016). Dalam kenyataannya, mahasiswa kesulitan memecahkan masalah di kehidupan sehari-hari, sehingga mahasiswa tidak 
mampu menyelesaikan masalah matematika kontekstual. Hal ini disebabkan mahasiswa terbiasa dengan mengoperasikan langsung tanpa memperhatikan prosesnya. Tentu saja hal tersebut akan menimbulkan kebingungan bagi mahasiswa karena konsep matematika bersifat deduktif, artinya untuk mempelajari konsep B yang mendasarkan pada konsep A, maka terlebih dahulu harus menguasai konsep A. Tanpa memahami konsep A, tidak mungkin mahasiswa menguasai konsep B.

Oleh karena itu, peneliti tertarik untuk melakukan penelitian proses berpikir mahasiswa dalam memecahkan masalah pada fungsi pembangkit, khususnya yang melibatkan masalah kontekstual. Masalah matematika kontekstual merupakan materi yang membutuhkan penguasaan mahasiswa dalam menggunakan strategi pemecahan masalah, sehingga proses berpikir mahasiswa ketika menggunakan strategi pemecahan masalah perlu ditelusuri khususnya pada materi fungsi pembangkit.

Dari beberapa penelitian yang telah dilakukan, tampak belum ada penelitian yang membahas tentang proses berpikir mahasiswa khususnya ketika memecahkan masalah menggunakan tahapan Polya. Begitu juga penelitian-penelitian tentang fungsi pembangkit, seperti yang dilakukan oleh Sukoriyanto, Nusantara, Subanji, \& Chandra (2016) yang meneliti tentang pemecahan masalah kombinasi. Seperti yang telah dikemukakan di atas, dapat diketahui pentingnya mengetahui proses berpikir mahasiswa dalam memecahkan masalah, sehingga tujuan penelitian ini adalah untuk mendeskripsikan proses berpikir mahasiswa dalam memecahkan masalah fungsi pembangkit berdasarkan kemampuan tinggi, sedang, dan rendah berdasarkan tahapan pemecahan masalah dari Polya.

\section{METODE PENELITIAN}

Penelitian ini merupakan penelitian deskriptif eksploratif yang bertujuan untuk menggali, memaparkan atau mendeskripsikan proses berpikir mahasiswa dalam menyelesaikan masalah fungsi pembangkit. Selain itu, pendeskripsian ini akan ditinjau dari perbedaan kemampuan mahasiswa yang didasarkan pada Indeks Prestasi Komulatif (IPK) dan tes kemampuan awal, sehingga mahasiswa dikelompokkan berkemampuan tinggi, sedang, dan rendah.

Sumber data dalam penelitian ini adalah mahasiswa Pendidikan Matematika, Universitas PGRI Adi Buana Surabaya yang memprogram mata kuliah Matematika 
Diskrit. Mahasiswa tersebut saat ini berada pada semester 6 dan bukan mahasiswa transfer ataupun mahasiswa recourse. Selain itu, sumber data juga mempertimbangkan kemampuan mahasiswa yaitu mahasiswa dengan kemampuan tinggi, sedang, dan rendah.

Metode penelitian yang digunakan yaitu metode tes dan wawancara. Metode tes digunakan untuk menentukan subjek penelitian yang akan diwawancarai. Tes yang digunakan dalam penelitian ini disebut sebagai Tes Kemampuan Awal (TKA), dimana soal tes terdiri atas 4 soal dan waktu mengerjakan 100 menit. Sedangkan, metode wawancara digunakan untuk menggali informasi sedalam-dalamnya dari subjek penelitian yang telah diperoleh melalui metode tes. Selama wawancara berlangsung, subjek penelitian diminta untuk mengerjakan tes uraian sebanyak 4 masalah, dan hanya 1 masalah yang dianalisis oleh peneliti. Selama memecahkan masalah, subjek diminta untuk mengungkapkan apa yang dipikirkannya menggunakan think aloud.

Data dikatakan valid apabila informasi yang diperoleh pada saat wawancara mengenai tes yang telah dikerjakan, subjek dapat menjawab sesuai dengan informasi yang sebenarnya, bukan mengada-ada. Jika informasi yang didapatkan belum valid, maka dilakukan triangulasi untuk memeriksa keabsahan data yaitu melakukan wawancara kembali dengan sumber sehingga didapatkan informasi yang benar-benar valid (Moleong, 2001).

Teknik analisis data yang digunakan dalam penelitian ini adalah: (1) tahap reduksi data. Dalam tahap ini, dilakukan proses menggolongkan, membuang yang tidak perlu, dan mengorganisasikan data mentah yang diperoleh dari lapangan. Sedangkan data yang diperoleh dari hasil wawancara dituangkan secara tertulis dengan cara mentranskripsi ucapan yang dituturkan subjek selama proses wawancara dan mendengarkan kembali rekaman wawancara. (2) tahap penyajian data. Dalam tahap ini sekumpulan informasi digabungkan dan dikategorikan sehingga memungkinkan terjadinya penafsiran, pemberikan makna, dan pengertian untuk menarik kesimpulan. Selain itu, juga dilakukan pemilahan dan pengkodean pada hasil transkripsi, dilanjutkan dengan memasukkan data pada format yang telah disiapkan. Hal ini bertujuan untuk mempermudah dalam menganalisis data hasil penelitian yang telah ditranskripsi, dan (3) tahap penarikan kesimpulan atau verifikasi. Penarikan kesimpulan berdasarkan hasil analisis tentang proses berpikir mahasiswa dalam memecahkan masalah matematika kontekstual dan masalah matematika formal. 


\section{HASIL DAN PEMBAHASAN}

Dari data IPK dan Tes Kemampuan Awal diperoleh subjek yang mempunyai kemampuan tinggi, sedang, dan rendah. Subjek kemampuan tinggi diberikan kode SA, subjek kemampuan rendah diberikan kode SB, dan subjek kemampuan rendah diberikan kode SC. Setelah itu, peneliti memberikan masalah pada masing-masing subjek, subjek diminta untuk memecahkan masalah tersebut menggunakan think aloud untuk mengungkapkan proses berpikirnya dalam memecahkan masalah fungsi pembangkit yang diberikan oleh peneliti. Selama subjek memecahkan masalah, peneliti juga menuliskan hal-hal yang ditemukan di lapangan untuk membantu analisis data.

Setelah subjek memecahkan masalah menggunakan think aloud, peneliti juga melakukan wawancara secara mendalam pada masing-masing subjek untuk mengkonfirmasi pekerjaan yang dilakukan. Dari hasil wawancara tersebut, peneliti melakukan analisis data untuk mendeskripsikan proses berpikir mahasiswa dalam memecahkan masalah tentang fungsi pembangkit. Berikut ini hasil diskusi hasil pekerjaan subjek ditinjau dari kemampuannya.

\section{Subjek kemampuan tinggi (SA)}

Dalam memecahkan masalah, SA membaca masalah setiap kalimatnya dan berusaha untuk memahami maksud masalah. Setelah subjek memahami masalah, subjek menuliskan dalam lembar jawaban yang diberikan informasi apa yang diketahui dari masalah. Subjek merencanakan pemecahan dengan menuliskan syarat dari informasi yang diketahui, dan menuliskannya dalam fungsi pembangkit. Setelah itu, subjek melakukan penghitungan untuk mendapatkan solusi dari masalah yang diberikan. Pada tahap ini, subjek memeriksa kembali hasil pekerjaan yang dilakukan. Adapun hasil pekerjaan subjek berkemampuan tinggi dapat dilihat pada Gambar 1 berikut. 


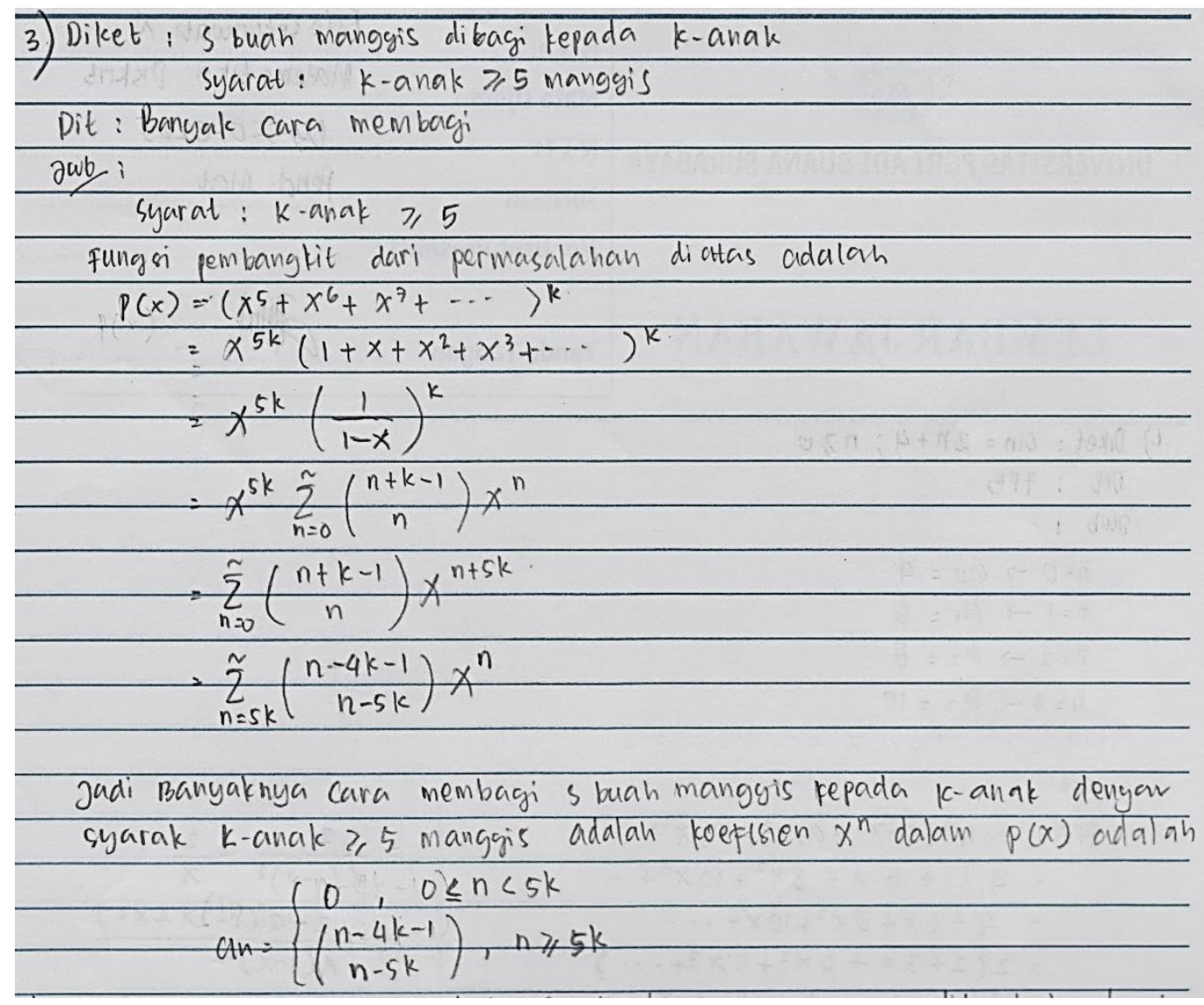

Gambar 1. Hasil Pekerjaan SA Subjekberkemampuan tinggi

Pertama kali, yang dilakukan subjek berkemampuan tinggi adalah membaca masalah yang disajikan. Pada tahap ini, subjek berusaha memahami masalah dengan menuliskan informasi yang dipahami dari masalah yang diberikan. Subjek menuliskan dalam lembar jawaban yang diberikan informasi apa yang diketahui dari masalah. Subjek merencanakan pemecahan masalah dengan menuliskan syarat dari informasi yang diketahui, dan menuliskannya dalam fungsi pembangkit. Subjek menuliskan fungsi pembangkit berdasarkan syarat yang diberikan yaitu " $k$ anak $\geq 5$ ". Setelah itu, subjek melakukan penghitungan untuk mendapatkan solusi dari masalah yang diberikan dan menjawab masalah.

\section{Subjek kemampuan sedang (SB)}

Dalam memecahkan masalah, SB membaca masalah setiap kalimatnya dan berusaha untuk memahami maksud masalah. SB membaca masalah sebanyak dua kali dan setelah subjek memahami masalah, subjek menuliskan dalam lembar jawaban yang diberikan informasi apa yang diketahui dari masalah. Subjek merencanakan pemecahan dengan menuliskan syarat dari informasi yang diketahui, dan menuliskannya dalam 
fungsi pembangkit. Setelah itu, subjek melakukan penghitungan untuk mendapatkan solusi dari masalah yang diberikan. Pada tahap ini, subjek memeriksa kembali hasil pekerjaan yang dilakukan. Adapun hasil pekerjaan subjek pada gambar 2 berikut.

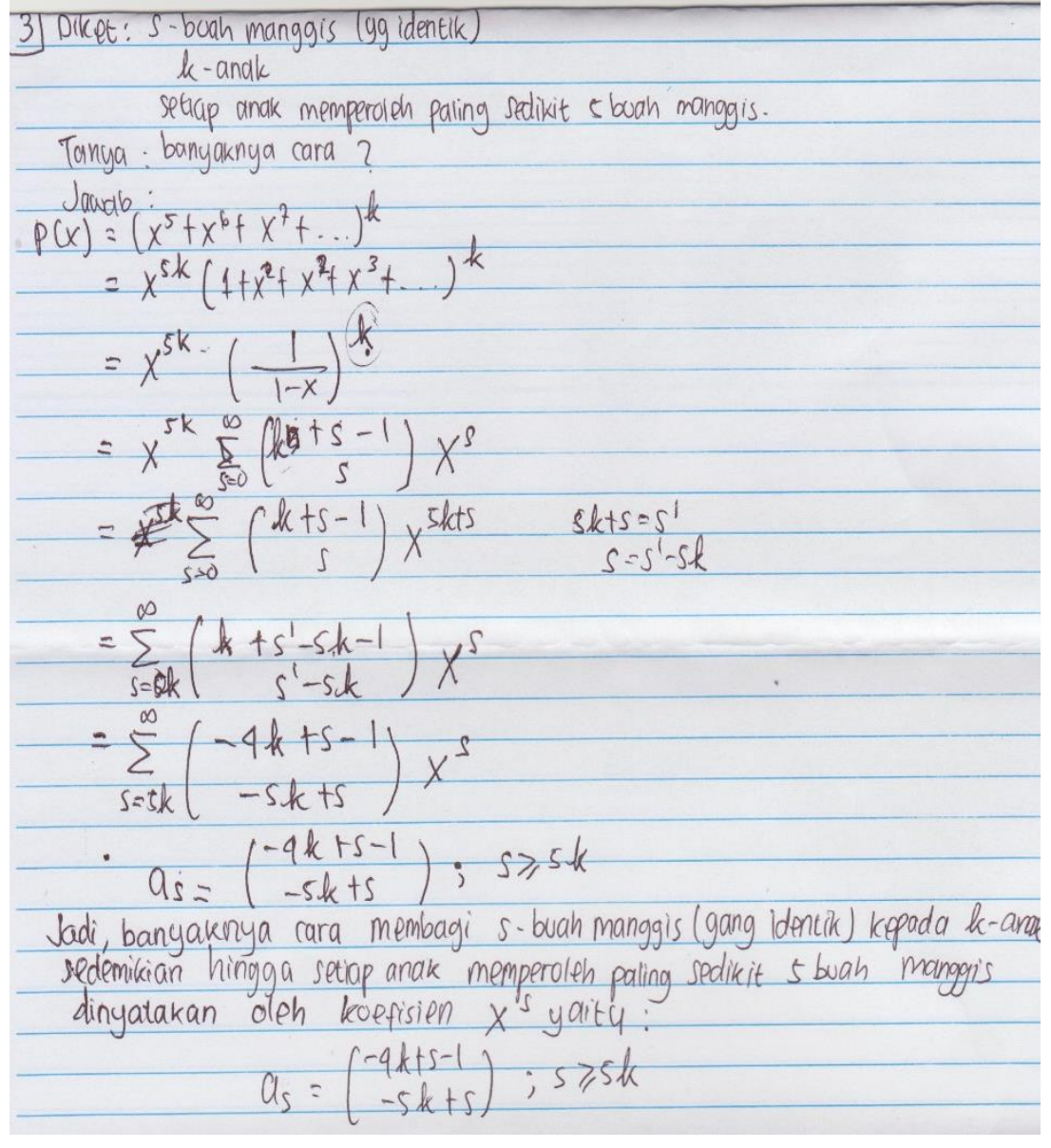

Gambar 2. Hasil Pekerjaan SB mahasiswa Berkemampuan Sedang

SB membaca masalah sebanyak dua kali, subjek membaca masalah dengan bersuara pelan. Karena subjek masih mengalami kebingungan maka subjek membaca untuk kedua kalinya dan setelah subjek memahami masalah, subjek menuliskan dalam lembar jawaban yang diberikan informasi apa yang diketahui dari masalah. Subjek merencanakan pemecahan dengan menuliskannya dalam fungsi pembangkit. Setelah itu, subjek melakukan penghitungan untuk mendapatkan solusi dari masalah yang diberikan, kemudian memberikan jawaban akhir dari masalah. Sebelum memastikan jawaban yang diberikan, subjek juga memeriksa kembali langkah-langkah yang dilakukannya dalam memecahkan masalah. 


\section{Subjek kemampuan rendah (SC)}

Dalam memecahkan masalah, SC membaca masalah setiap kalimatnya dan berusaha untuk memahami maksud masalah. SC membaca setiap kalimat dari masalah sebanyak dua kali, dalam hal ini SC tidak menuliskan informasi yang diketahui dari masalah. Setelah membaca, subjek merencanakan pemecahan dengan menuliskan syarat dari informasi yang diketahui, dan menuliskannya dalam fungsi pembangkit. Setelah itu, subjek melakukan penghitungan untuk mendapatkan solusi dari masalah yang diberikan. Pada tahap ini, subjek memeriksa kembali hasil pekerjaan yang dilakukan, tetapi subjek tidak mampu menjawab sampai menemukan solusi. Dari hasil wawancara, subjek SC mengalami kebingungan untuk menjawab masalah yang diberikan. Adapun hasil pekerjaan subjek dapat dilihat pada gambar 3 berikut.

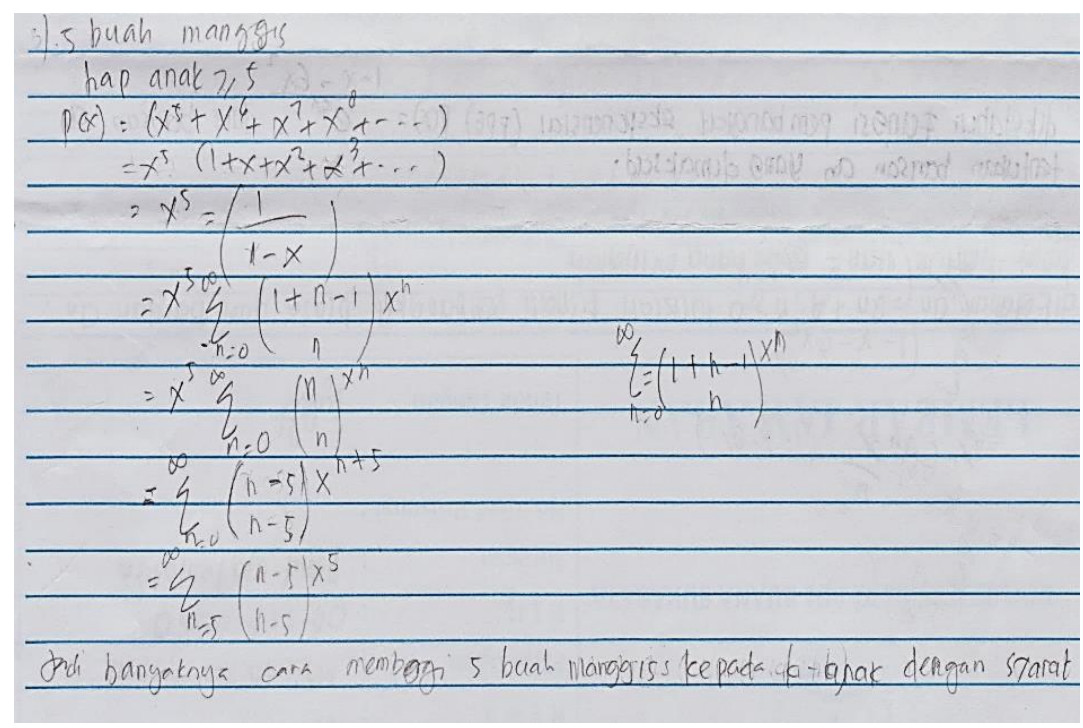

Gambar 3. Hasil Pekerjaan Siswa Berkemampuan Rendah

Dalam memecahkan masalah kontekstual, SC membaca setiap kalimat dari masalah sebanyak dua kali. SC juga mengalami kesulitan ketika membaca satu kali masalah dan hal ini diulangi kembali. Dalam hal ini SC tidak menuliskan informasi yang diketahui dari masalah. Setelah membaca, subjek merencanakan pemecahan dengan menuliskan syarat dari informasi yang diketahui, dan menuliskannya dalam fungsi pembangkit. Setelah itu, subjek melakukan penghitungan untuk mendapatkan solusi dari masalah yang diberikan. Setelah memberikan jawaban, subjek juga memeriksa kembali hasil pekerjaan yang dilakukan, tetapi subjek tidak mampu menjawab sampai menemukan solusi. Dari hasil wawancara, subjek SC mengalami kebingungan untuk menjawab masalah yang diberikan. 
Berdasarkan jawaban yang diberikan subjek berkemampuan tinggi, sedang, dan rendah tampak adanya perbedaan dalam memahami masalah. Subjek berkemampuan tinggi, mampu memahami masalah dengan membaca satu kali saja masalah yang disajikan. Sedangkan pada subjek berkemampuan sedang dan rendah mampu memahami masalah dengan dua kali membaca. Hal ini seperti penelitian yang dilakukan oleh Mairing (2017) bahwa pemecah masalah cenderung membaca masalah beberapa kali untuk memahami masalah. Kegiatan ini merupakan strategi pemecahan masalah yang melibatkan membaca pemahaman (Meyer, 2014; Panasuk \& Beyranevand, 2011).

Dalam mengkonstruk model mental tidak ada subjek yang mengalami kesulitan dan ketiga subjek mampu merencanakan pemecahan masalan, hal ini tidak sejalan dengan hasil penelitian Mairing (2017). Hal ini dikarenakan ketiga pemecah masalah mempunyai skema pemecahan masalah yang baik didasarkan pada informasi sintaksis dan semantic pada masalah yang disajikan (Liang, Tsai, Chang, Lin, \& Su, 2016). Selain itu, dalam merencanakan, pemecah masalah dapat juga menggunakan representasi yang berbedabeda sesuai dengan pemahamannya (Mielicki \& Wiley, 2016). Dari hasil penelitian ini, ketiga subjek menggunakan representasi aljabar sebagai hasil dari konstruk model mentalnya.

Jadi, dapat dikatakan subjek yang mempunyai perbedaan kemampuan juga mempunyai perbedaan cara dalam memecahkan masalah. Hal ini senada dengan penelitian Bakry dan Bakar (2015) yang menyatakan bahwa proses berpikir siswa yang berkemampuan tinggi, sedang, dan rendah memecahkan masalah menggunakan HOTS berbeda.

\section{SIMPULAN DAN SARAN}

Berdasarkan uraian di atas, dapat disimpulkan bahwa proses berpikir siswa dengan kemampuan tinggi runtut dalam memecahkan masalah fungsi pembangkit. Hal ini dikarenakan SA mampu menjelaskan dari awal menyelesaikan sampai mengarah pada kesimpulan yang merupakan solusi dari masalah. Akan tetapi, mahasiswa dengan kemampuan tinggi tersebut mempunyai kekurangan yaitu melakukan kekeliruan yang disebabkan kurang tepat melakukan pengecekan alasan dari soal yang ada. Proses berpikir mahasiswa dengan kemampuan sedang juga runtut seperti dalam memecahkan masalah formal karena mampu menjelaskan dari awal menyelesaikan sampai mengarah pada 
kesimpulan. Sedangkan, proses berpikir mahasiswa dengan kemampuan rendah kurang runtut karena melakukan kesalahan dalam pengecekan hasil yang kurang baik. Solusi yang diperoleh subjek dengan kemampuan rendah juga kurang sesuai. Subjek dengan kemampuan rendah tidak memenuhi indikator langkah-langkah pemecahan masalah menurut Polya.

Saran dari hasil penelitian ini, agar pendidik memperhatikan kemampuan peserta didiknya dalam memecahkan masalah karena jika peserta didik kesulitan dalam menyelesaikan konsep matematika formal yang bersifat deduktif. Selain itu, mengetahui proses berpikir dapat dijadikan acuan merancang proses pembelajaran yang lebih baik, misalnya menggunakan reciprocal teaching (Meyer, 2014). Perlu ada penelitian lebih lanjut tentang proses berpikir pada materi yang lain khususnya pada mahasiswa jika ditinjau dari kerangka kerja asimilasi dan akomodasi (Sukoriyanto, Nusantara, Subanji, \& Chandra, 2016), level berpikir mahasiswa ketika memecahkan masalah fungsi pembangkit (Rahman \& Ahmar, 2016), dan learning trajectory mahasiswa ketika memecahkan masalah fungsi pembangkit (Prayitno \& Kurniawan, 2017).

\section{DAFTAR RUJUKAN}

Anggo, M. (2009). Metakognisi Mahasiswa Calon Guru Dalam Memecahkan Masalah Matematika Kontekstual. Surabaya: Universitas Negeri Surabaya. (Disertasi tidak Dipublikasikan)

Bakry, \& Bakar, N. Bin. (2015). The Process of Thinking among Junior High School Students in Solving HOTS Question. International Journal of Evaluation and Research in Education, 4(3), 138-145.

Liang, C., Tsai, S., Chang, T., Lin, Y., \& Su, K. (2016). A Meaning-based English Math Word Problem Solver with Understanding, Reasoning and Explanation. In COLING 2016, the 26th International Conference on Computational Linguistic: System Demonstrations (pp. 151-155).

Mairing, J. P. (2017). Thinking Process of Naive Problem Solvers to Solve Mathematical Problems. International Education Studies, 10(1), 1-11. doi:https://doi.org/10.5539/ies.v10n1p1

Marpaung, Y. (1993). Metode Kualitatif untuk Mempelajari Representasi Pengetahuan Matematika dalam Pikiran Siswa. Jogjakarta.

Meyer, K. (2014). Making meaning in mathematics problem-solving using the reciprocal teaching approach. Literacy Learning: The Middle Years, 22(2), 7-14. 
Mielicki, M. K., \& Wiley, J. (2016). Alternative representations in algebraic problem solving: When are graphs better than equations? The Journal of Problem Solving, 9(1), 3-12. doi: https://doi.org/10.7771/1932-6246.1181

Moleong, L. J. (2001). Metodologi penelitian kualitatif. Bandung: PT Remaja Rosdakarya.

NCTM. (2000). Principles and standards for school mathematics. United States of America: The National Council of Teachers of Mathematics Inc. Retrieved from www.nctm.org

Panasuk, R. M., \& Beyranevand, M. L. (2011). Preferred representations of middle school algebra students when solving problems. The Mathematics Educator, 13(1), 32-52.

Prayitno, L. L., \& Kurniawan, A. P. (2017). Learning trajectory siswa dalam memecahkan masalah kelipatan persekutuan terkecil ditinjau dari kemampuan matematika. Jurnal Review Pembelajaran Matematika, 2(1), 15-27. doi: https://doi.org/10.15642/jrpm.2017.2.1.15-27

Polya, G. (2004). How to solve it: A new aspect of mathematical method. New Jersey: Princeton University Press.

Rahman, A., \& Ahmar, S. A. (2016). Exploration of Mathematics Problem Solving Process Based on The Thinking Level of Students in Junior High School. International Journal of Environmental \& Science Education, 11(14), 7278-7285.

Subanji, S., \& Nusantara, T. (2016). Thinking Process of Pseudo Construction in Mathematics Concepts. International Education Studies, 9(2), 17. doi:https://doi.org/10.5539/ies.v9n2p17

Sukoriyanto, S., Nusantara, T., Subanji, S., \& Chandra, T. D. (2016a). Students 'thinking process in solving combination problems considered from assimilation and accommodation framework. Educational Research and Reviews, 11(16), 1494 1499. doi: https://doi.org/10.5897/ERR2016.2811

Sukoriyanto, S., Nusantara, T., Subanji, S., \& Chandra, T. D. (2016b). Students' Errors in Solving the Permutation and Combination Problems Based on Problem Solving Steps of Polya. International Education Studies, 9(2), 11-16. doi:https://doi.org/10.5539/ies.v9n2p11

Suryanti, S. (2015). Peningkatan kepercayaan diri dan kemampuan pemecahan masalah mahasiswa pada mata kuliah matematika diskrit melalui discovery learning. DIDAKTIKA: Jurnal Pemikiran Pendidikan, 22(1), 64-73. doi:10.1234/didaktika.v22i1.148 